\title{
A 30,000-year brGDGTs-based temperature record from North China Plain
}

\author{
MINMINSUN $^{12 *}$, SHILINGYANG ${ }^{123}$ \\ ${ }^{1}$ Key Laboratory of Cenozoic Geology and Environment, \\ Institute of Geology and Geophysics, Chinese Academy \\ of Sciences, Beijing, China \\ (*correspondence:sunminmin@mail.iggcas.ac.cn) \\ ${ }^{2}$ University of Chinese Academy of Sciences, Beijing, China \\ ${ }^{3}$ CAS Center for Excellence in Life and Paleoenvironment, \\ Beijing, China
}

The North China Plain is a very important grain production area in China. Its weather and climate is strongly influenced by the East Asian monsoon system, which has aroused widespread concern. Quantitative paleotemperature reconstruction provides insight into the mechanism of climate change and climate prediction in the East Asian monsoon domain. Here we reconstruct air temperature for the North China Plain during the last $30 \mathrm{ka}$, based on the distribution of microbial tetraether membrane lipids GDGTs in the fluviallacustrine sediments of Ningjinbo. Our results show that the timing of the Last Glacial Maximum and the Holocene Thermal Maximum in the North China Plain (about $21 \mathrm{ka}$ and $5.8 \mathrm{ka}$, respectively) is consistent with that recorded in lake and loess deposits in northern China. The reconstructed mean annual air temperature(MAAT) during the Last Glacial Maximum is about $15.3^{\circ} \mathrm{C}$, and that during the Holocene Thermal Maximum is about $18.9^{\circ} \mathrm{C}$. The climate warmed by $3.6^{\circ} \mathrm{C}$ from the Last Glacial Maximum to the Holocene Thermal Maximum, which is lower than the mean temperature rise over China $\left(5.6^{\circ} \mathrm{C}\right)^{[1]}$ and the globe $\left(5-6^{\circ} \mathrm{C}\right)^{[2]}$. We suggest that the brGDGTs-based temperature during glacial periods may be more biased towards summer conditions compared to that during interglacials, due to glacial-interglacial changes in the length of brGDGTs production period, which requires further investigation.

[1] Wu (2019) Science China Earth Sciences, 62, 1269-1278.

[2] Snyder(2016) Nature, 538, 226-228.

\section{Acknowledgements}

This study was supported by the National Natural Science Foundation of China (Grants 41725010 and 41672175). 